\title{
A History of Japanese Venture
}

\section{Businesses}

Koji NAKANO ${ }^{\text {a) }}$

\begin{abstract}
In the first quarter century after World War II, small- and medium-sized businesses were discussed in Japan with no relation to discussions about startups in other countries. For some time after the war, a two-tiered structure theory with a pessimistic approach toward small- and medium-sized businesses was at the fore, and later discussions of medium-sized companies never really focused on startups. However, from the 1970s, with the influence of the U.S., the Japanese-English term "venture businesses" began to take off. Venture capital began to be provided to startups, and these businesses came to be discussed with great expectations.
\end{abstract}

Keywords: venture business, two-tiered structure theory, medium-sized company theory, venture boom

a) Faculty of Business Administration, Toyo University, 5-28-20, Hakusan, Bunkyo-ku, Tokyo, Japan, nakano@toyo.jp

A version of this paper was presented at the ABAS Conference 2016 Autumn (Nakano, 2016).

(C) 2017 Koji Nakano. This is an Open Access article distributed under the terms of the Creative Commons Attribution License, which permits unrestricted reuse, distribution, and reproduction in any medium, provided the original work is properly cited. 


\section{Prehistory: "Two-tiered Structure Theory" and "Medium-sized Company Theory" in Japan}

In the first quarter century after World War II, small- and medium-sized businesses were discussed in Japan with no relation to discussions regarding startups in other countries (e.g., Ries, 2011). The two-tiered structure theory promulgated by Arisawa (1957) noted the coexistence of two tiers: (1) capitalistic management based on large-scale bureaucratic and rational organizations centered primarily on technologies transplanted from foreign countries (production technologies, production management, and product design) and (2) family-managed small- and medium-sized businesses that were built around existing technologies (Odaka, 1989). This concept was described in the Annual Report on Japanese Economy of 1957 as "being a two-tiered structure within a country similar to the structure of advanced and developing nations" and quickly spread from there (Odaka, 1984). As to Japan's employment structure, this Annual Report on Japanese Economy pointed out Japan's modern companies on the one side, with small companies and family-owned micro enterprises having premodern labor-management relationships on the other, and very little in between. This two-tiered structure theory can be summarized by the following five points (Kiyonari, 1990):

(1) The Japanese economy is built on modern fields (large companies) and premodern fields (small- and medium-sized companies).

(2) Unlike modern sectors where necessary labor is determined by capital and technology, sectors with little capital have changing combinations of labor and capital due to lower incomes. Since people work even though income does not meet labor reproduction costs, there is little potential for unemployment, leading to full employment. 
(3) The economies of Western advanced nations are a single, homogenous structure.

(4) The Japanese economy is growing at a quantitatively rapid pace, although it is qualitatively lagging behind.

(5) Premodern sectors are stagnating, and there is no ability to break out of that stagnation developing within the economy.

On the basis of these ideas, the expansion of the small- and medium-sized business area was tied to an increase in small- and medium-sized businesses built upon low wages and long work hours, making growth both unlikely and undesirable (Takahashi, 2007). This meant that entrepreneurial activities for promoting the creation of startups were looked down upon.

In contrast, Nakamura (1964) developed a theory of mid-sized companies, referring to those companies in between large firms and micro enterprises. Noting the appearance and establishment of mid-sized companies in Japan in the 1960s from case studies of 40 growing firms, the theory explained this phenomenon from the perspectives of changes in the external atmosphere, namely, greater social divisions of labor caused by a more advanced industrial structure and income improvements, as well as the perspectives of obtaining management resources by companies, such as technological capabilities, marketing, and the establishment of mass production systems through domain expertise.

The qualitative definition of mid-sized companies given by Nakamura (1990) is as follows:

(a) Independence (they are not affiliates of large companies)

(b) Able to procure social capital via the stock market

(c) Individual or family leadership that remains strong

(d) Products in unique fields with a high level of production concentration or market share 
In other words, mid-sized companies did not take market share from dominant existing large companies; rather, they grew in markets that were expanding in the high-growth economy. ${ }^{1}$ However, though this theory filled the gap in the two-tiered structure theory between small- and medium-sized businesses on the one hand and large companies on the other, it did not refer to startups in any way.

\section{The Emergence of "Venture Businesses"}

"Venture business" is an English term created in Japan that gained use in the 1970s. Chikao Tsukada worked in the Ministry of International Trade and Industry, or MITI (today's Ministry of Economy, Trade and Industry [METI]), and participated in the 2nd Boston College Management Seminar held in May 1970. This was Japan's first introduction to venture businesses, or the groups of small companies that were created in the U.S. in the 1950s in practically every industry, particularly the electronic equipment and information industries in the latter half of the 1960s (Kiyonari, Nakamura, \& Hirao, 1971). However, the term "venture business" was not used in the U.S. or U.K., and startups were never referred to as "venture businesses" in everyday conversation (Yonekura, 2001).

Kiyonari, Nakamura, and Hirao (1971) promulgated this term in Japan and defined a venture business as "an $R \& D$ - or design development-intensive creative new firm." They further stated, "These start out as small companies, though unlike traditional newly formed small companies, they have unique raison d'etre and executives that create a corporate culture that can attract talented and creative people with advanced, specialized capabilities. They are high-profit firms, and many of them are growing rapidly." Despite the fact that the term

1 Takahashi (2015) presented the hypothesis that the heretofore unused existence of startup management services creates "economies of growth, which then step by step creates growth regardless of company size." 
"venture business" was not used prior to this time, such companies have always existed in Japan (Kanai, 2002). Sony (established in 1946), Honda (1948), Omron (1948), and Kyocera (1959) are examples of such companies that have grown to become large enterprises in Japan.

\section{The First "Venture Boom"}

Once the term "venture business" appeared, private venture capital was also established in Japan. Prior to 1963, companies set up to provide venture capital to small- and medium-sized firms were established by the government in Tokyo, Nagoya, and Osaka. The first private venture capital firm in Japan was Kyoto Enterprise Development (KED), established by Kyoto's financial community in 1972. In the same year, the former Long-Term Credit Bank of Japan created Japan Enterprise Development, and in 1973, Japan Associated Finance (today's JAFCO) was established by Nomura Securities. These efforts allowed the procurement of capital through equity finance by small- and medium-sized companies that were previously getting capital through regional or second-tier regional banks or credit unions.

There was a strong influence from the U.S. on Japanese companies (Matsuda, 1998). In the U.S., companies that provided capital to small- and medium-sized businesses were formed in 1958, and in the late 1960s, primarily private large firms and financial institutions joined the venture capital fray, with Arthur Rock forming the first investment business association in 1969.

A venture business creation boom occurred in Japan between 1970 and 1973. The "Plan for Remodeling the Japanese Archipelago," announced by soon-to-be prime minister Kakuei Tanaka in 1972, spurred economic growth, and venture businesses began to appear, driven by expectations for entrepreneurs based on technologies 
unique to Japan and technology from the West. FANUC Corporation, established in 1972, was one such company representative of this first venture boom, along with Roland (1972), Mos Food Services (1972), and Seven-Eleven Japan (1973) (Kanai, 2002).

\section{Theory of "Venture Businesses"}

The first venture boom came to a close as the first oil shock in 1973 caused many venture businesses to fail. However, the position of venture businesses in the world of industry was clear (Matsuda, 2014). The "Small Business and Micro-Enterprise Startup Survey," "Survey of Urban Startup Firms," and "Survey of Regional Startup Firms," published by the People's Finance Corporation Research Department (1977), all pushed the idea of venture businesses (Takahashi, 2007).

In particular, the "Survey of Urban Startup Firms" published in 1970 defined venture businesses as those companies having advanced, specialized capabilities and with an important role in the social division of labor in a de-industrializing society. It further noted characteristics such as "commercializing new technologies, developing unique and new sales and marketing methods based on specialized knowledge, and pioneering through creative activities." The surveys mentioned above showed that small and micro enterprises with high productivity increased, startup firms in major metropolitan areas existed in certain fields, and startup firms were not limited to urban areas. This made a massive impact on society, changing the pessimistic view of small- and medium-sized companies advocated by the two-tiered structure theory and presenting a positive view of startups. 


\section{The Second "Venture Boom"}

Between 1982 and 1986, Japan experienced a second venture boom. Deregulation catalyzed the creation of much venture capital from securities firms, banks, and foreign firms, and this period was even called the "venture capital boom" (Matsuda, 1998). Revisions to the commercial code in 1981 made it possible for non-public companies to issue warrant bonds. In 1982, it became possible to provide venture capital through investment business associations, and in 1983, Japan Associated Finance (today's JAFCO) created a Japanese-style investment business association as a private association. Further, that year witnessed deregulation for disclosure criteria in the over-the-counter open market.

Meanwhile, the Small- and Medium-Sized Business Investment Promotion Act was passed in the U.S. in 1980, and in the same year, the Bayh-Dole Act, which granted rights to inventors, was also passed. The next year, the capital gains tax rate was lowered from $28 \%$ to $20 \%$, creating a boom in initial public offerings (IPOs).

At this time, the micro-enterprise region from Tokyo's Ota Ward to Kawasaki $^{2}$ was recognized as a rare industrial area globally, with advanced technologies and product development capabilities. It was considered that the skills and technologies accumulated within this network improved the productivity of large factories for mass production and enabled the rapid development of products (Imai, 1984). In actuality, research-focused venture businesses that focused on advanced, cutting-edge technologies in electronics, new materials, and biotechnology were established. The second oil shock ended around this time, and the Japanese industry shifted away

2 Inamizu and Wakabayashi (2009) covered the business relationships in the industrial area in Tokyo's Ota Ward in recent years in detail. Inamizu and Wakabayashi (2013) presented the dynamic framework for the industry agglomeration seen in this region. 
from manufacturing to tertiary industries such as distribution and services, represented by such companies as HIS (established in 1980), Softbank (1981), Culture Convenience Club (1982), and Aucnet (1984) (Kanai, 2002).

However, even as venture capital began to compete more for the investment of large sums in venture businesses, the 1985 Plaza Accord brought on the rapid valuation of the yen, and major venture businesses at the time, such as Dainichi Sangyo, Kangyo Denki Kiki, and Dainichi Kiko, failed one after the other from 1986. Consequently, the period that followed was even called the "venture winter" (Matsuda, 1998).

\section{The Third "Venture Boom"}

The third venture boom began in 1995, amid the long-term slump following the bursting of Japan's economic bubble (Matsuda, 2014). Unlike the second boom, which began with an improving economy and ended with a recession, the third venture boom began with regulatory reforms by the government. For example, the Smalland Medium-Sized Business Promotion Act was enacted in 1995, and venture foundations were formed throughout the country in 1996. In 1997, stock options were allowed, along with the trading of non-public shares, and regulations were put in place allowing for professors in national universities to hold corporate positions and for limited liability investment business association. In 1998, the creation of technology licensing organizations was promoted through the University Technology Transfer Promotion Act, and the 1999 enactment of the Act on Special Measures for Industry Revitalization (Japan's version of the Bayh-Dole Act) enabled the attribution of patents from outsourced government-funded research and development to private companies.

It was during this time that a global information and 
communication revolution via the Internet came into being. The company Netscape was created in 1994 and kicked off web browser development, and the release of Microsoft's Windows 95 in 1995 promoted the use of the Internet. Amazon.com was formed in 1994, followed by Google in 1997, with many "dot-com" technology companies established throughout the world. Stock prices of IT companies in the U.S. rose rapidly between 1999 and 2000, and investment in biotechnology companies also grew in that period.

Likewise, in Japan, the Tokyo Stock Exchange created Mothers in 1999, and in 2000, NASDAQ Japan was created as a joint venture (established in 1999) between the NASDAQ in the U.S. and Softbank on the Osaka Stock Exchange. ${ }^{3}$ With the implementation of standards for venture businesses that "allow going public [for companies] with future growth prospects and revenues," venture businesses on the verge of growth now had a way to get capital on public markets, leading to the creation of companies such as On the EDGE (established in 1996 and later renamed to Livedoor), Kakaku.com (1997), CyberAgent (1998), E mercury (1999, later renamed to Mixi), AnGes MG (1999), DeNA (1999), freebit.com (today's Freebit, 2000), and DRECOM (2001). However, improprieties around the sales of mobile phones reported by the media in 2000 caused the stock prices of Hikari Tsushin to plummet, along with those of other Internet-related firms, bringing an end to Japan's "Internet boom."

In 2001, share prices plummeted in the U.S. as well. With an increase in interest rates by the Federal Reserve, along with the terrorist attacks of September 11, the NASDAQ index fell to 1,000 units and the dot-com bubble ended. Moreover, in the U.S., the

3 The Tokyo Stock Exchange (1st and 2nd sections) seems to be the end point for growing and mature public companies until the 1990's, with its stricter listing rules making it extremely difficult for newly formed venture businesses to go public there. 
fraudulent accounting of Enron Corporation in 2001 led to its collapse and the enactment of the Sarbanes-Oxley Act in 2002. Worldcom also collapsed in the same year due to fraudulent accounting, and with the U.S. Securities and Exchange Commission imposing stricter rules for internal controls and governance, the costs for IPOs and maintaining a public company increased, resulting in a dramatic decrease in IPOs in the U.S.

In contrast, around 130 new companies went public in Japan every year from the end of the Internet boom to 2007. This was due to government policies that began with the "Ideas from 1,000 Venture Companies from Universities" (i.e., ideas from university ventures for creating 1,000 companies over a period of five years starting in 2002) proposed by then-MITI minister Takeo Hiranuma. A science and technology council was created in the Cabinet Office, and intellectual and property cluster regions were designated wherein universities would be used for economic redevelopment.

However, Takafumi Horie, CEO of Internet venture darling Livedoor, was arrested for suspected violations of the Securities Act in 2006 (and convicted in 2011), and around that time, IPO standards for each new market were made more stringent. This, along with internal controls systems put in place with the fiscal year ending in March 2009, made for a stricter process for going public. In 2008, the U.S. subprime mortgage crisis brought on the collapse of Lehman Brothers, putting a damper on the Nikkei stock average. IPOs in Japan also dropped off dramatically, ending the third venture boom.

\section{Conclusion}

Discussions of Japan's small- and medium-sized businesses did not focus on startups for the first quarter century after World War II. However, beginning in 1970 and with the influence of the U.S., the abundant funding of startups primarily through venture capital 
began, raising expectations and initiating discussions around "venture businesses," a unique English phrase developed in Japan in contrast to the pessimistic view of small- and medium-sized businesses that existed prior to that time. However, even after the third venture business boom, funding for startups in Japan still has not moved from traditional to equity financing. Further consideration of this topic will be left to a future paper.

\section{Acknowledgments}

This work was supported by JSPS Grant-in-Aid for Publication of Scientific Research Results, Grant Number JP16HP2004.

\section{References}

Arisawa, H. (1957). Nihon ni okeru koyomondai no kihonteki kangaekata [Basic concept of employment problems in Japan]. In Japan Productivity Center (Ed.), Nihon no keizaikouzou to koyoumondai [Economic structure and employment problems in Japan] (pp. 322). Tokyo, Japan: Japan Productivity Center (in Japanese).

Imai, K. (1984). Network sangyo-soshiki [Network of industrial organization]. Kikan Gendai Keizai [Contemporary Economics], 58, 413 (in Japanese).

Inamizu, N., \& Wakabayashi, T. (2009). A new model of Japanese industrial districts combining supplier-side and purchaser-side logic. Annals of Business Administrative Science, 8, 1-19. doi: 10.7880/abas.8.1

Inamizu, N., \& Wakabayashi, T. (2013). A dynamic view of industrial agglomeration: Toward an integration of Marshallian and Weberian theories. Annals of Business Administrative Science, 12, 13-29. doi: $10.7880 /$ abas. 12.13

Kanai, K. (2002). Venture kigyo toha [What is a venture company]. In 
K. Kanai, \& R. Tsunoda (Eds.), Venture kigyou keiei ron [Theory of venture business] (pp. 1-26). Tokyo, Japan: Yuhikaku (in Japanese). Kiyonari, T. (1990). Chyusyokigyoudokuhon (2nd ed.) [Reading book of small business]. Tokyo, Japan: Toyokeizaishinpousya (in Japanese).

Kiyonari, T., Nakamura, S., \& Hirao, K. (1971). Venture business: Zuno wo uru chisana daikigyo [Venture business: A "small" big company that sells brains]. Tokyo, Japan: Nihonkeizaishinnbunnsya (in Japanese). Matsuda, S. (1998). Venture kigyoron [Theory of venture business]. Tokyo, Japan: Nihonkeizaishinbunsya (in Japanese).

Matsuda, S. (2014). Venture kigyoron (4th ed.) [Theory of venture business]. Tokyo, Japan: Nihonkeizaishinbunsyuppansya (in Japanese).

Nakamura, S. (1964). Cyuken kigyou ron [Theory of mid-sized firms]. Tokyo, Japan: Toyokeizaishinpousya (in Japanese).

Nakamura, S. (1990). Shin chyuken kigyou ron [New theory of mid-sized firms]. Tokyo, Japan: Toyokeizaishinpousya (in Japanese).

Nakano, K. (2016, December). A history of Japanese venture business. Paper presented at ABAS Conference 2016 Autumn, University of Tokyo, Japan.

Odaka, K. (1984). Rodo shijyo bunseki: Nihonteki tenkai [Analysis of labor market: Development in Japan]. Tokyo, Japan: Iwanamisyoten (in Japanese).

Odaka, K. (1989). Nijyukouzou [Two-tiered structure]. In R. Nakamura, \& K. Odaka (Eds.), Nihonkeizaishi: Vol. 6 Nijyukouzou [Economic history: Vol. 6 Two-tiered structure] (pp. 133-184). Tokyo, Japan: Iwanamisyoten (in Japanese).

People's Finance Corporation Research Department (1977) Syoureisaikigyou no sonritsu jyouken [Existence condition of small business]. Informally published document (in Japanese).

Ries, E. (2011). The lean startup: How today's entrepreneurs use continuous innovation to create radically successful businesses. New York, NY: Crown Business.

Takahashi, N. (2007). Chyusyokigyo no image [Image of small business]. In T. Yasuda, N. Takahashi, K. Kutsuna, \& Y. Honjyo (Eds.), Text: lifecycle kara mita chyusyokigyou ron [Textbook: Small business 
studies from the perspective of life cycle management]. Tokyo, Japan: Doyukan (in Japanese).

Takahashi, N. (2015). An essential service in Penrose's economies of growth. Annals of Business Administrative Science, 14, 127-135. doi: 10.7880/abas. 14.127

Yonekura, S. (2001). Venture business to seido to shiteno venture capital [Venture business and venture capital as institution]. In Hitotsubashi University Innovation Center (Eds.), Innovation management nyumon [Introduction of innovation management] (pp. 362-363). Tokyo, Japan: Nihonkeizaishinbunsya (in Japanese). 